\title{
SUCCESSIVE CULTIVATION OF MAIZE AND AGRICULTURAL PRACTICES ON ROOT COLONIZATION, NUMBER OF SPORES AND SPECIES OF ARBUSCULAR MYCORRHIZAL FUNGI
}

\author{
Rosilaine Carrenho $^{1 *}$; Eraldo Schunk Silva ${ }^{1}$; Sandra Farto Botelho Trufem ${ }^{2}$; Vera Lucia Ramos Bononi ${ }^{2}$ \\ ${ }^{1}$ Universidade Estadual de Maringá, Departamento de Biologia, Maringá, PR, Brasil. nstituto de Botânica, Micologia, \\ São Paulo, SP, Brasil
}

Submitted: November 08, 2000; Returned to authors for corrections: August 03, 2001; Approved: December 14, 2001

\begin{abstract}
A large number of propagules and a broad spectrum of species are two important components of ecosystem (including agroecosystem) sustainability. Previous studies carried out in temperate areas showed that repeated monoculture leads to a decrease in the species abundance of arbuscular mycorrhizal fungi (AMF). This study evaluated the influence of maize monoculture and its agricultural practices on AMF during three consecutive cropping years in a Brazilian field. At the end of each cycle, soil and root samples were evaluated for species composition, spore populations and root colonization by AMF. The AMF community present during this period was scored according to the Spearman rank correlation and Principal Components Analysis. The mean percent root colonization values for the three cultivation periods were: $66.9,60.7$ and 70.5, respectively. Seven species were detected in the first year, Scutellospora persica being the most abundant (24.1\% of spores) and Glomus macrocarpum the most observed (100\% of samples). In the second year, Glomus etunicatum was the species with the greatest number of spores (24.7\%) and, like G. macrocarpum, the most frequently observed $(90 \%)$ in a community of thirteen. In the third year, twenty-three AMF species were identified, Scutellospora sp. 1 being the most abundant (17.4\%), and Gigaspora decipiens and Glomus claroideum the most frequent (both with a relative frequency of 70\%). The main soil factors influencing root colonization and sporulation by AMF were $\mathrm{pH}$ (and related properties), phosphorus and organic matter contents.
\end{abstract}

Key words: monoculture, maize, mycorrhiza, diversity of species.

\section{INTRODUCTION}

Arbuscular mycorrhizal fungi (AMF) have been associated with improved plant growth for over 100 years (34). Generally, AMF increase the absorption of mineral nutrients present in the soil and are mainly important in nutrient poor soil (27). Even when AMF are not associated with the roots of all plant species in a certain area, they can provide indirect benefit. AMF develop hyphae externally to the roots of the host species, which improve the structure of the soil by maintaining the association between decomposing organic matter and minerals (23). Also, when external hyphae become disconnected from their photobionts, their decomposition provides nutrients to the non-mycorrhizal plants in the immediate vicinity.

In agroecosystems, alterations in cultivation regime, crop plants and cultural practices may influence the AMF community $(9,16,19)$. The environment may select AMF species which may or may not be adapted to the local conditions and which may or may not be favorable to plant development (32). Competition between AMF species, in terms of their ability to colonize roots, may also be influenced by environmental conditions. Therefore, alterations in the composition of AMF species can lead to a better or a worse relationship between fungi and plants, resulting in benefit or injury to plant development.

\footnotetext{
* Corresponding author. Mailing address: Universidade Estadual de Maringá, Departamento de Biologia, Av. Colombo, 5790. 87020-900. Maringá, PR, Brasil. Tel: (+5544) 261-4668. E-mail: rcarrenho@uem.br
} 
In order to evaluate the influence of agricultural practices on AMF development we carried out a field study in three different stages. In the first stage, we cropped maize for three successive years and observed the fungal responses to chemical and physical soil changes. In the second stage, we multiplied AMF spores previously established in maize (stage one) in a sterile substrate (river sand) to evaluate species multiplication in different host plants (maize, sorghum and peanut). In the last stage, these host plants were grown in 24 different substrates and their influence on AMF development was observed. Data about root colonization, number of spores and species diversity during three successive years in a Brazilian field is presented and related to soil properties.

\section{MATERIALS AND METHODS}

\section{Characterization of the experimental area}

The experimental area was located in the Biological Reserve and Experimental Station of Moji-Guaçu, São Paulo State $\left(22^{\circ} 18^{\prime} \mathrm{S}\right.$ and $\left.47^{\circ} 11^{\prime} \mathrm{W}\right)$ at an elevation of $680 \mathrm{~m}$ (4). The climate is class Cwa (Köppen classification) with dry winters and median temperatures of $16^{\circ} \mathrm{C}$ in the coldest month and $24^{\circ} \mathrm{C}$ in the hottest month. The atmospheric temperature and relative humidity obtained during the period of maize culture (199496) are shown in Fig. 1.

The soil in the cultivated area was a red-yellow sandytextured, dystrophic and type A moderate latosoil (3), whose chemical properties were evaluated during the three years of cultivation (Table 1).

\section{Experimental design}

The experiment was set up in a completely randomized design, where three adult plants comprised an experimental unit. Ten units were taken for a total of thirty plants. The plants were chosen after division of the area into ten blocks ( 5 x $5 \mathrm{~m}$ each). In each block, soil and root samples were taken from three different plants, homogenized and considered to comprise a replicate unit.

\section{Plants}

The host species used was maize (Zea mays L.), var. IACTaiúba, based on its economic importance, in addition to its wide study in Brazil $(5,13,14,22,29,35)$.

\section{Agricultural practices}

Maize cultivation was carried out according to standard practice. The soil was prepared by incorporating the total residues of the previous culture (Hibiscus esculenta $\mathrm{L}$.) with the manual sowing of maize seeds (December 1994). At the end of October 1994, soil acidity was adjusted by the addition of $50 \mathrm{Kg} /$ ha of calcareous dolomite, corresponding to $2.272 \mathrm{mg} . \mathrm{L}^{-1}$ of soil. In the beginning of September 1995 and September 1996, half as much $(25 \mathrm{Kg} / \mathrm{ha})$ calcareous dolomite was incorporated in the soil, following the cultivation lines. In the middle of October, the soil was fertilized with ammonium sulfate, simple superphosphate and potassium chloride, in the ratios NPK 4-14-8. The fertilizer was applied at $37.5 \mathrm{~g} /$ linear meter on the day of sowing, along the plantation lines. Thirty-five days after the emergence of the seedlings, $26 \mathrm{~g}$ of ammonium sulfate per linear meter was applied, approaching $50.8 \mathrm{Kg} / \mathrm{ha}$ of nitrogen. Following chemical analysis, this fertilization program was repeated in the other two cycles. Weeding was carried out during the whole cultivation period to avoid the growth of invader plants. The plants were irrigated daily, except during the rainy periods.

\section{Collection of samples}

At the end of the reproductive cycle (April 1995, February 1996 and February 1997), roots and rhizospheric soil were sampled from 30 plants. The whole root system was removed, the rhizospheric soil was separated from the roots and put into a plastic box and the samples (from each block) were mixed to prepare a $500 \mathrm{~g}$ composite sample. The finest roots in each root system were sampled separately. The roots were stored in plastic bags for further processing in the laboratory.

\section{Evaluation of root colonization}

Percent root colonization values were measured using the intersection of quadrants method (12), after staining the roots with trypan blue (25).

\section{Isolation and quantification of spores}

Spores were isolated from the soil by wet sieving and sucrose flotation methods $(11,20)$. The number of spores was expressed as the number of individuals per $100 \mathrm{~g}$ of dry soil. Frequency of occurrence represents the number of times a species was observed.

Table 1. Chemical and physical-chemical properties of the soil in the experimental field from Fazenda Campininha over three successive years.

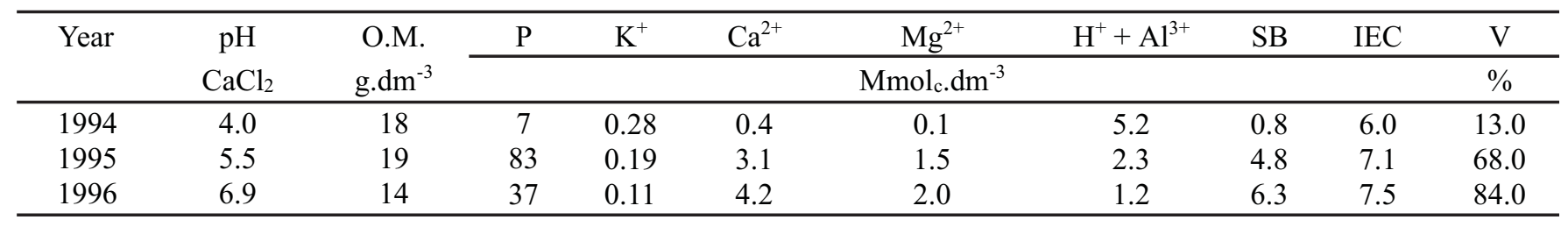

$\mathrm{OM}=$ organic matter; $\mathrm{H}^{+}+\mathrm{Al}^{3+}=$ potential acidity; $\mathrm{SB}=$ sum of bases; IEC = ion exchange capacity; $\mathrm{V}=$ saturation of bases. 


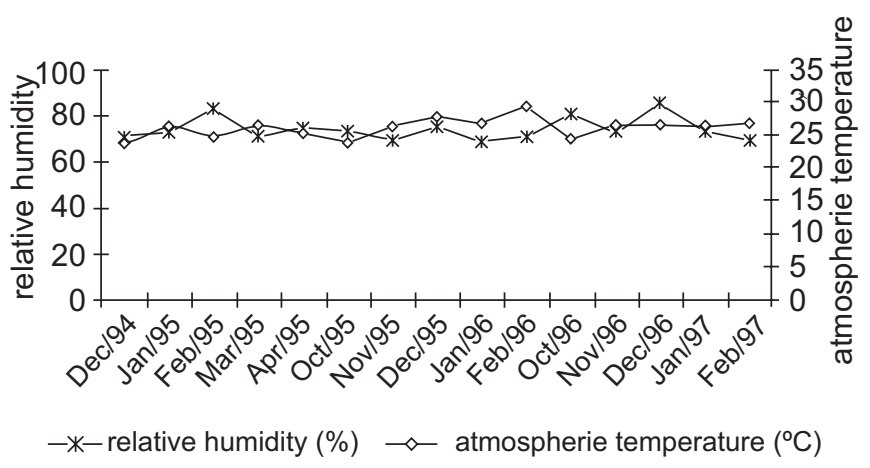

Figure 1. Climatic field data obtained during trhee culture cycles of maize. Data provided by Fischer e Citrosolo Agrícola Ltda.

\section{Statistical analysis}

Percentages of root colonization were evaluated by variance analysis, followed by Tukey's test $(\mathrm{P} \leq 0.05)$. Then Spearman rank correlation coefficients were calculated to examine relationships between root colonization, number of spores from individual species and soil characteristics. Principal components analysis (PCA) was performed between AMF spore populations and some soil properties to determine which factors were the responsible for the variability in spore number.

\section{RESULTS AND DISCUSSION}

\section{Root colonization}

The percentages of root colonization (RC) varied little (56.7 to $87 \%$ ) during three years of cultivation. Significant differences were observed $(\mathrm{P}=0.03)$ only among those obtained between the second and third years. The average values for the three cycles $(1994,1995,1996)$ were $66.9 \%, 60.7 \%$ and $70.5 \%$, respectively.

The percentages of root colonization obtained in this study may be considered high because in studies involving maize in Brazil, they varied from 6 to $39.4 \%(5,13,14,22,29,35)$. These differences become more significant when the data is compared with that obtained from fertile soils in temperate regions. Hetrick et al. (18) obtained values varying from 2 to $8.7 \%$ in maize cultivated in four different areas in the state of Kansas (USA).

Although accentuated differences had been verified in the chemical and physical-chemical soil properties in the course of three years of cultivation, the only soil property that presented significant influence on RC was the content of OM, which was inversely related to the intraradical development of AMF, as demonstrated by Spearman correlation analysis $(-0.504)$ (Table 2). Few studies have described the effects of organic matter on root colonization. Their diversified data are inconclusive (10, 37). Indeed, in these studies, the effects of organic matter on root colonization by AMF are based on available phosphorus content after the action of phosphatases excreted by saprophytic microorganisms on organic matter (21).

Soil $\mathrm{pH}$ is a factor that normally affects the development of mycorrhizal symbiosis $(17,28,31)$, mainly at acidic levels when the soil presents high $\mathrm{Al}^{+}$and $\mathrm{H}^{+}$contents, which are toxic to $\operatorname{AMF}(26,30)$ and cause the adsorption of phosphorus, making it unavailable to the plant.

The $\mathrm{P}$ content of the soil is recognizably the main factor that regulates the establishment and the efficiency of AM symbiosis (6). The high concentration of $\mathrm{P}$ in the soil $\left(83 \mathrm{mmolc} . \mathrm{dm}^{-3}\right)$, verified

Table 2. Significant interactions between root colonization, spore populations from individual AMF species, and soil properties, according to the Spearman correlation analysis.

\begin{tabular}{lcccccccc}
\hline \multicolumn{1}{c}{ Sppore populations } & $\mathrm{pH}$ & $\mathrm{O} . \mathrm{M}$. & $\mathrm{P}$ & $\mathrm{Ca}^{2+}$ & $\mathrm{Mg}^{2+}$ & $\mathrm{K}^{+}$ & $\mathrm{H}^{+}+\mathrm{Al}^{3+}$ & $\mathrm{IEC}$ \\
\hline A. longula & $0.407^{*}$ & $-0.407^{*}$ & - & $0.407^{*}$ & $0.407^{*}$ & $-0.407^{*}$ & $-0.407^{*}$ & $0.407^{*}$ \\
E. colombiana & - & $0.366^{*}$ & $0.576^{*}$ & - & - & - & - & - \\
G. claroideum & 0.667 & $-0.667^{*}$ & - & $0.667^{*}$ & $0.667^{*}$ & $-0.667^{*}$ & $-0.667^{*}$ & $0.667^{*}$ \\
G. clarum & - & $0.407^{*}$ & $0.407^{*}$ & - & - & - & - & - \\
G. etunicatum & - & $0.725^{*}$ & $0.784^{*}$ & - & - & - & - & - \\
G. invermaium & $-5.569^{*}$ & - & $-0.648^{*}$ & $-0.569^{*}$ & $-0.569^{*}$ & $0.569^{*}$ & $0.569^{*}$ & $0.569^{*}$ \\
G. macrocarpum & - & - & $0.463^{*}$ & - & - & - & - & - \\
G. occultum & - & $0.639^{*}$ & $0.770^{*}$ & - & - & - & - & - \\
S. fulgida & $0.407^{*}$ & $0.407^{*}$ & - & $0.407^{*}$ & $0.047^{*}$ & $-0.40 *$ & $-0.407^{*}$ & $0.407^{*}$ \\
S. gilmorei & $0.478^{*}$ & $0.478^{*}$ & - & $0.478^{*}$ & $0.478^{*}$ & $-0.478^{*}$ & $-0.478^{*}$ & $0.478^{*}$ \\
S. minuta & $0.607^{*}$ & $0.607^{*}$ & - & $0.607^{*}$ & $0.607^{*}$ & $-0.607^{*}$ & $-0.607^{*}$ & $0.607^{*}$ \\
Senacents persica & $-0.438^{*}$ & $0.578^{*}$ & - & $-0.438^{*}$ & $-0.438^{*}$ & $0.438^{*}$ & $0.438^{*}$ & $-0.438^{*}$ \\
Scutellospora sp. 1 & $0.607^{*}$ & $0.607 *$ & - & $0.607^{*}$ & $0.607^{*}$ & $-0.607^{*}$ & $-0.607^{*}$ & $0.607^{*}$ \\
Root colonization & - & $0.504^{*}$ & - & - & - & - & - & - \\
\hline
\end{tabular}

$* \mathrm{P} \leq 0.05 ;$ IEC $=$ ion exchange capacity; $\mathrm{OM}=$ organic matter. 
in the second year, seemed to have been a negative factor for RC. This agrees with previously obtained data $(1,2,18)$, despite no significant correlation being detected between these variables.

It is possible that the lack of correspondence between $\mathrm{pH}, \mathrm{P}$ and $\mathrm{RC}$ is due to the establishment of distinct AMF communities (Table 3), which must have been formed by species adapted to the yearly environmental conditions. Thus, despite the environmental conditions having been different (mainly soil properties), the association of the plant with different AMF (as regards their physiological and ecological requirements) may explain the similarity of the root colonization levels.

\section{AMF: relative number of spores and frequency of occurrence}

The number of AMF species increased progressively from the first year of cultivation to the last in a total of 25 taxa. Of these, ten belonged to the genus Glomus, eight to Scutellospora, five to Acaulospora, one to Gigaspora and one to Entrophospora (Table 3).
Using this cultivation system, more than one year passed before any change in AMF composition was observed. The number of species, according to spore population, increased progressively from 7 to 23 . This pattern was also observed in three successive cycles of Prosopis spp. by Stutz and Morton (33), who explained that it resulted from a late sporulation induction mediated by some environmental factors on the nonsporulating species. Thus, we can suppose that those species had been present in the field since the first year, but sporulated only in the second or third cultivation, providing a more exact idea about AMF species composition.

The AMF species richness obtained in this experiment is similar to that found in other studies involving maize monoculture $(13,14,22,29,35)$. The number of species in previous studies varied from 9 to 22 and the number of species in common with the present study varied from 3 to 10 .

The species most frequently found in the studies cited above are: Acaulospora appendicula, A. foveata, A. longula,

Table 3. Occurrence of the AMF species in rhizospheres of maize plants cultivated for three years (1994-1996) at the Fazenda Campininha. Letters after specific names are used in Figure 2, representing the taxa observed.

\begin{tabular}{|c|c|c|c|c|c|c|c|c|c|}
\hline \multirow{2}{*}{ AMF species } & \multicolumn{3}{|c|}{1994} & \multicolumn{3}{|c|}{1995} & \multicolumn{3}{|c|}{1996} \\
\hline & NS & $\mathrm{Fr}$ & $\mathrm{CV}$ & NS & $\mathrm{Fr}$ & $\mathrm{CV}$ & $\mathrm{NS}$ & $\mathrm{Fr}$ & $\mathrm{CV}$ \\
\hline A. appendicula (a) & 17 & 6 & 96.2 & 19 & 3 & 163.5 & 6 & 2 & 224.9 \\
\hline A. foveada (b) & - & - & - & 23 & 3 & 161.5 & 16 & 2 & 144.9 \\
\hline A. longula (c) & - & - & - & - & - & - & 6 & 4 & 179.1 \\
\hline A. scrobiculata (1) & 23 & 6 & 106.6 & 61 & 5 & 120.5 & 110 & 6 & 91.5 \\
\hline A. tuberculata $(\mathrm{d})$ & - & - & - & 16 & 3 & 177.2 & 6 & 1 & 179.1 \\
\hline E. colombiana $(\mathrm{e})$ & - & - & - & 90 & 6 & 93.2 & 9 & 3 & 169.3 \\
\hline G. decipiens (w) & 25 & 7 & 86.9 & 26 & 4 & 139.5 & 80 & 7 & 97.0 \\
\hline G. claroideum (f) & - & - & - & - & - & - & 145 & 7 & 93.2 \\
\hline G. clarum (g) & - & - & - & 7 & 3 & 191.0 & - & - & - \\
\hline G. etunicatum (h) & - & - & - & 223 & 9 & 62.6 & 6 & 1 & 316.2 \\
\hline G. geosporum (i) & - & - & - & - & - & - & 6 & 2 & 224.9 \\
\hline G. globiferum (j) & - & - & - & 5 & 1 & 316.2 & 3 & 1 & 316.2 \\
\hline G. invermaium (k) & 41 & 8 & 91.5 & - & - & - & 3 & 1 & 316.2 \\
\hline G. macrocarpum (m) & 54 & 10 & 44.6 & 133 & 9 & 56.0 & 113 & 6 & 69.4 \\
\hline G. maculosum ${ }^{c}$ (n) & - & - & - & - & - & - & 3 & 1 & 316.2 \\
\hline G. mosseae (o) & - & - & - & - & - & - & 8 & 2 & 18.9 \\
\hline G. occultum (p) & - & - & - & 49 & 8 & 45.5 & 8 & 2 & 210.8 \\
\hline S. calospora (q) & - & - & - & - & - & - & 9 & 2 & 224.9 \\
\hline S. fulgida $(\mathrm{r})$ & - & - & - & - & - & - & 9 & 3 & 169.3 \\
\hline S. gilmorei (s) & - & - & - & - & - & - & 58 & 4 & 153.0 \\
\hline S. heterogama $(\mathrm{t})$ & 38 & 8 & 65.4 & 123 & 6 & 116.1 & 27 & 3 & 164.7 \\
\hline S. minuta $(\mathrm{u})$ & - & - & - & - & - & - & 161 & 7 & 88.3 \\
\hline S. persica (v) & 127 & 7 & 73.6 & 62 & 6 & 99.1 & - & - & - \\
\hline Scutellospora sp. 1 (x) & - & - & - & - & - & - & 166 & 6 & 89.3 \\
\hline Scutellospora sp. $2(\mathrm{z})$ & - & - & - & - & - & - & 3 & 2 & 224.9 \\
\hline Number of taxa & 7 & & & 13 & & & 23 & & \\
\hline
\end{tabular}

${ }^{a} \mathrm{n}=10$ replicates; ${ }^{\mathrm{b}}$ Acaulospora appendicula was synonymized with $A$. gerdemanni $(24) ;{ }^{\mathrm{c}}$ Glomus maculosum was synonymized with Glomus claroideum (36). NS = number of spores; $\mathrm{Fr}=$ frequency of occurrence; $\mathrm{CV}=$ coefficient of variation. 
A. scrobiculata, Gigaspora decipiens, Glomus etunicatum, G. invermaium, G. mosseae, G. occultum, Scutellospora calospora and $S$. heterogama. All of these species were isolated in the present experiment, through all cultivations, except $A$. longula, G. mosseae and S. calospora, which occurred only in the third year (Table 3).

Spearman rank correlation coefficients showed some species had their number of spores influenced by chemical and physical soil properties (Table 2). $\mathrm{pH}, \mathrm{Ca}^{2+}, \mathrm{Mg}^{2+}, \mathrm{IEC}, \mathrm{K}^{+}$and $\mathrm{H}^{+}+\mathrm{Al}^{3+}$ had a significant influence on the spore number of eight AMF species, as well as organic matter and phosphorus contents (eleven and six species, respectively). When we analyze the data coming from Spearman rank correlation analysis, we consider each soil factor separately. This is one of the ways to detect which factors are operating on AMF development, but it is not necessarily the best, since many factors can operate together. In order to reduce the number of variables (soil properties) and to detect structure in the relationships between variables, we selected five soil characters based on Spearman rank correlation results and data from related literature $(7,29)$, and extracted the principal components by combining two or more correlated variables into one factor (Principal Components Analysis). Based on eigenvalues (data not shown), a measure which defines how much each factor explains total variance, we determined that Factors 1 and 2 were responsible for 59\% and $21 \%$ of all variability, respectively. Factor 1 was positively correlated with $\mathrm{pH}(0.98)$ and IEC $(0.97)$ and inversely with $\mathrm{H}^{+}+$ $\mathrm{Al}^{3+}(-0.98)$ and $\mathrm{OM}(-0.66)$ (Table 4). As the first three variables are closely related to each other, $\mathrm{pH}$ and organic matter were designated as the first principal component influencing the spore populations of AMF. The second principal component (Factor 2) was represented by phosphorus and organic matter (Table 4) and together influenced the distribution of AMF close to the yaxis (Fig. 2).

Factor 1 vs. Factor 2 plotting showed that the sporulating species found in each year remained in three groups (1, 2 and 3 ) settled in different positions, indicating specific responses of the fungi to variations in the factors indicated as limiting. Group

Table 4. Correlation between nominative variables and factors.

\begin{tabular}{lcc}
\hline \multicolumn{1}{c}{ Variables } & Factor 1 & Factor 2 \\
\hline Total number of spores (TNS) & 0.29 & 0.29 \\
Ion exchange capacity (IEC) & 0.98 & 0.15 \\
Phosphorus (P) & 0.49 & 0.83 \\
$\mathrm{H}^{+}+\mathrm{Al}^{3+}$ & -0.98 & -0.14 \\
$\mathrm{pH}$ & 0.98 & -0.08 \\
Organic matter (OM) & -0.66 & 0.70 \\
Coefficient of variation (CV) & 0.69 & -0.34 \\
\hline
\end{tabular}

Factor $1=\mathrm{pH}$ and organic matter; Factor $2=$ phosphorus and organic matter.
1 was positioned in the negative quadrant of Factors 1 and 2 (adversely affected by $\mathrm{pH}, \mathrm{P}$ and $\mathrm{OM}$ ); group 2 was plotted in the positive quadrant of Factor 2 and in the negative of Factor 1 (positively related to $\mathrm{P}$ and $\mathrm{OM}$ and negatively to $\mathrm{pH}$ ); and group 3 was positioned near the $\mathrm{x}$-axis ( 0 on the $y$-axis), on the positive side of Factor 1 (positively related to $\mathrm{pH}$ ). The following relationships were considered:

In the first year, spores of only seven taxa were collected (Table 3), with S. persica being the dominant species (39\% of spores). Most of the species detected occurred at high frequency, varying from 60 to $100 \%$ of the samples, with $G$. macrocarpum being the only species that was present in all samples. The small number of sporulating species was probably due to the high level of aluminum (typical of soil with a $\mathrm{pH}$ below 5.0), which is generally associated with inhibition of germination and hyphal growth of some AMF species $(15,31)$. Consequently, only $\mathrm{pH}$-tolerant species could colonize the roots, and at the end of the reproductive phase, when the plants were water stressed, they sporulated. Soil pH was seemingly an important feature in limiting AMF sporulation in this first year.

In the second year of cultivation, 13 AMF species were detected (Table 3), with G. etunicatum the dominant species (26.6\% of spores). Of the species which had sporulated in the first cultivation, two (A. appendicula and G. decipiens) remained with a small number of spores and three presented an average increase of more than $200 \%$ (Table 5). Of these, G. macrocarpum was positively related to the level of phosphorus (0.438) (Table 2). In this cycle, G. invermaium seems not to have found adequate conditions to sporulate. This behavior was probably due to the $\mathrm{pH}$ variations (4®5.5) and concentration of $\mathrm{P}(7 \circledast 83$ $\left.\mathrm{mmol}_{\mathrm{c}} \cdot \mathrm{dm}^{-3}\right)$, as indicated by the Spearman rank correlation coefficients ( -0.569 and -0.648 , respectively). In addition, the variations observed in the chemical and physical soil characteristics were favorable to the sporulation of seven more species (A. foveata, A. tuberculata, E. colombiana, G. claroideum, G. etunicatum, G. globiferum and G. occultum). In the second cycle the most frequent species were $G$. macrocarpum and G. etunicatum (both in $90 \%$ of the samples).

Table 5. Relative increase on AMF spore numbers present in the two first cultivation cycles.

\begin{tabular}{lccc}
\hline \multirow{2}{*}{ AMF species } & \multicolumn{2}{c}{ Number of Spores } & Relative \\
\cline { 2 - 4 } & Cultivation 1 & Cultivation 2 & Increase (\%) \\
\hline A. appendicula & 17 & 19 & - \\
G. decipiens & 25 & 26 & - \\
S. heterogama & 38 & 123 & 323 \\
A. scrobiculata & 23 & 61 & 265 \\
G. macrocarpum & 54 & 133 & 246 \\
S. persica & 62 & 129 & 208 \\
\hline
\end{tabular}




\section{Factor 2}

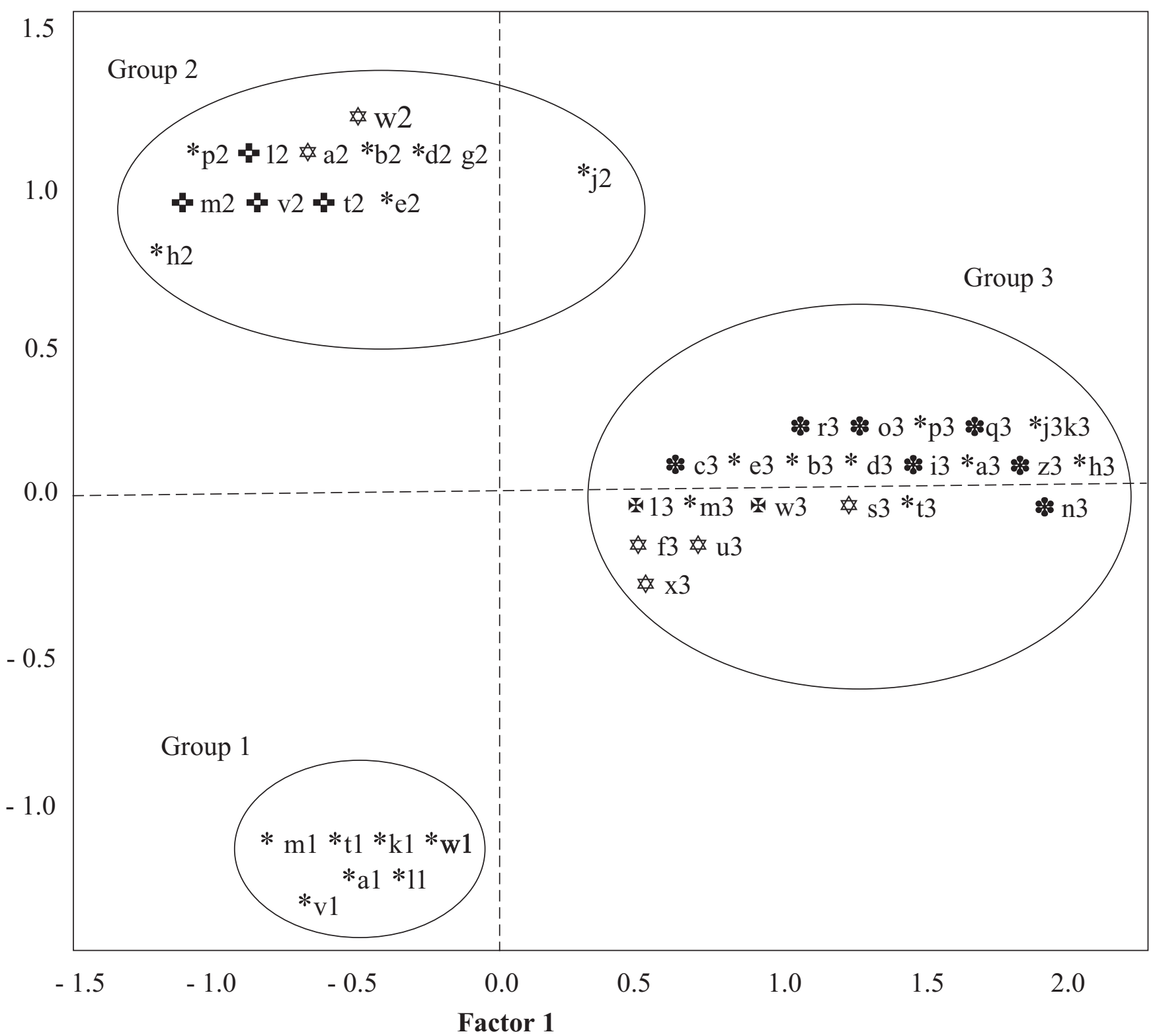

Figure 2. Main groups of AMF species formed by interaction of Factor 1 and Factor 2. See text and Table 3 for more details. Letters followed by numbers 1,2 or 3 correspond to species from cultivation 1, 2 and 3, respectively. Group 2 shows 3 different symbols before letters: $*$ and $\$$ corresponding to non-sporulating species in the $1^{\text {st }}$ cycle; no alteration on number of spores; and high sporulation, respectively. Group 3 showed 4 symbols, $*, *$, and $\$$ corresponding to decreased number of spores; low number of spores, only in the $3^{\text {rd }}$ cycle; increased number of spores; and large number of spores, only in the $3^{\text {rd }}$ cycle, respectively.

Differing sensitivities to P by AMF (8) may have affected the sporulation of the AMF present and thus improved the richness of the spore populations.

In the third year of cultivation, 23 taxa were identified (Table 3), from which five belonged to Acaulospora, one to Entrophospora, one to Gigaspora, nine to Glomus and seven to Scutellospora. Scutellospora sp. 1 (17.2\%), S. minuta (16.7\%) and G. claroideum $(15.1 \%)$ were the dominant species in the community, and also demonstrated wide distribution $(60,70$ and $70 \%$ of the samples, respectively). 
Four categories of species were identified according to their behavior in the sporulation process. The first category refers to the species that did not sporulate previously and that probably had better environmental conditions in the third cultivation, reaching excellent yield (Table 3). All of them presented positive correlation with $\mathrm{pH}$ (Table 2), occurring only when the soil acidity became extremely low (6.9). Apparently, these species were more sensitive to the concentration of $\mathrm{H}^{+}$and $\mathrm{Al}^{3+}$ in the soil (negative correlation) and were benefited by its reduction. It is possible that with the decreases in $\mathrm{H}^{+}$and $\mathrm{Al}^{3+}$ concentrations, more AMF species were successful in the colonization process, contributing to the increase in the number of spores observed in this year. Also, all the species were inversely related to the quantity of organic matter (positioned in the negative portion of the $y$ axis - Fig. 2), i.e. when the quantity of OM decreased, they had chances to sporulate. Degradation of OM increases soil acidity and further negative effect on the sporulation of these species may be intimately related to soil $\mathrm{pH}$. The second category refers to the species that did not find favorable conditions to sporulate in the first and second years; and although they did in the third cultivation, the yield presented was low (Table 3 ). Of these, only S. fulgida presented correlation with the soil $\mathrm{pH}(0.407)$ and organic matter (-0.407), despite the small number of spores (Table 2). The third category refers to the species that in the second cultivation had produced a large number of spores and in the third experienced a decrease (slight to conspicuous) in representation (Table 3). Species with greater decreases in the number of spores $(E$. colombiana, G. etunicatum and G. occultum), except $S$. heterogama, presented positive correlation with the levels of $\mathrm{OM}$ and $\mathrm{P}$ in the soil. Therefore, when the levels of $\mathrm{OM}$ and $\mathrm{P}$ decreased $\left(19 \AA 14 \mathrm{~g} \cdot \mathrm{dm}^{-3}\right.$ and $87{ }^{\circledR} 37 \mathrm{mmol}_{\mathrm{c}} \cdot \mathrm{dm}^{-3}$, respectively), the number of spores of these species also decreased, showing that these factors were limiting the sporulation of the rest. The last category included only two species $(G$. decipiens and A. scrobiculata), which had their sporulation increased in the third year of cultivation. Neither presented significant coefficients of correlation between the number of spores and soil properties, despite having increased their population of spores more than $100 \%$.

$S$. persica occurred in the first two cultivations and disappeared in the third. Correlation data (Table 2) showed that the sporulation of this species was negatively affected by the increase in $\mathrm{pH}(-0.438)$ and by the reduction in the quantity of $\mathrm{OM}$ in the soil (0.578).

When species composition was analyzed at the family level, it was observed that Gigasporaceae predominated in the communities of the third year of cultivation (Fig. 3). Spearman rank correlation coefficients showed that several Gigasporaceae species were positively influenced by $\mathrm{pH}, \mathrm{Ca}^{2+}, \mathrm{Mg}^{2+}, \mathrm{K}^{+}$, and IEC (Table 2). S. fulgida, S. gilmorei, S. minuta and

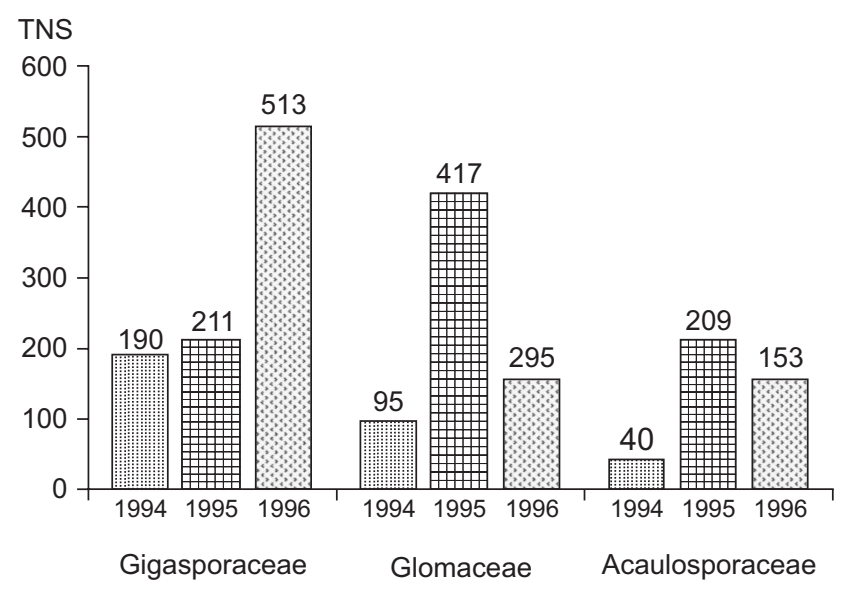

Figure 3. Total number of spores (TNS) of the families of Glomales in rhizospheres of maize, for three successive years (Moji-Guaçu, SP).

Scutellospora sp.1 had a larger number of spores when the above factors also had higher levels (third cycle). S. persica was the most abundant species in the first year and was negatively related to the soil factors cited above. S. calospora and Scutellospora sp.2 had very low abundance, while $S$. heterogama and G. decipiens had a larger number of spores; but they were very irregularly distributed in the soil samples. Thus, we did not verify any significant interaction in their spore production.

Glomineae sporulation was very similar for each year of cultivation. Glomaceae and Acaulosporaceae were more abundant in the second year than in the first or third. It was also observed that the numbers of spores of some Glomineae species (E. colombiana, G. clarum, G. claroideum, G. macrocarpum, and G. occultum) were correlated with the phosphorus contents in the soil (Table 2). The highest soil phosphorus concentration in the second year of cultivation probably stimulated or did not inhibit the spore germination and the intraradical colonization of Glomineae species. Consequently, these colonizing species may have predominated in the root cortical zone, sporulated, and increased their representation in the community. Hetrick et al. (18) worked in four agricultural areas in the state of Kansas (USA), where maize cultivation occurred for several years, and observed that in two of these areas, sporulation was mutually exclusive among representatives of Glomaceae and Gigasporaceae. The soil type was the same in the two areas and sampling occurred at the same time. The different features were $\mathrm{pH}$, phosphorus, and copper and iron concentrations. In the area where Glomaceae dominated, $\mathrm{pH}$ was less acid (6.1 vs. 5.4), phosphorus concentration was larger (56 vs. $25 \mu \mathrm{g} / \mathrm{g}$ soil) and copper and iron concentrations were 
smaller ( $0 v s .1 \mu \mathrm{g} / \mathrm{g}$ soil and 13 vs. $57 \mu \mathrm{g} / \mathrm{g}$ soil, respectively). Again, a positive relationship between phosphorus concentration and number of Glomaceae in the arbuscular mycorrhizal community was observed, indicating that these fungi have a greater tolerance to soil phosphorus concentration.

In summary, conventional agricultural practices over three cycles of maize cultivation modified soil characteristics, including $\mathrm{pH}$ (and related properties), organic matter and phosphorus concentrations, which were the main features influencing AMF root colonization and sporulation.

\section{ACKNOWLEDGEMENTS}

We would like to thank Dr. Marcos Mecca and M.Sc. João del Giudice Neto from Fazenda Campininha for accompanying the experiment in the field, Dr. Marlene Lima from Instituto Agronômico de Campinas, Seção de Genética for providing the maize seeds and Dr. Walter Valerio Filho from Universidade Estadual Paulista, Faculdade de Engenharia de Ilha Solteira for doing the initial statistical analysis of the data.

\section{RESUMO}

\section{Cultivo sucessivo de milho e práticas agrícolas sobre a colonização radical, número de esporos e de espécies de fungos micorrízicos arbusculares}

Elevado número de propágulos e de espécies são componentes importantes para manter a sustentabilidade dos ecossistemas, incluindo agrossistemas. Estudos desenvolvidos em áreas temperadas indicaram que monocultivo prolongado conduziu ao decréscimo na abundância de esporos e de espécies de fungos micorrízicos arbusculares (FMA). O presente estudo avaliou a influência da monocultura de milho e de suas práticas culturais sobre o desenvolvimento de FMA durante três anos sucessivos de cultivo em campo. Ao final de cada ciclo, amostras de solo e raízes foram avaliadas quanto à composição de espécies, populações de esporos e colonização radical por FMA. As mudanças da composição das comunidades de FMA estabelecidas durante estes anos foram avaliadas a partir da correlação de Spearman e da Análise dos Componentes Principais. As percentagens médias de colonização radical foram: $66,9,60,7$ e 70,5, respectivamente. No primeiro ano, sete espécies foram detectadas, sendo Scutellospora persica a mais abundante ( $24,1 \%$ dos esporos) e Glomus macrocarpum a espécie mais frequente $(100 \%$ das amostras). No segundo ano, Glomus etunicatum foi a espécie com maior número de esporos $(24,7 \%)$ e, juntamente com $G$. macrocarpum, foi a mais frequentemente observada $(90 \%)$ numa comunidade de treze espécies. No terceiro ano, vinte e três espécies de FMA foram identificadas, sendo Scutellospora sp.
1 a mais abundante (17,4\%), e Gigaspora decipiens e Glomus claroideum as espécies mais frequentes (ambas em 70\% das amostras). As principais causas de variação que puderam ser identificadas foram $\mathrm{pH}$ e concentrações de fósforo e matéria orgânica no solo.

Palavras-chave: monocultura, milho, micorriza, diversidade de espécies

\section{REFERENCES}

1. Amijee, F.; Tinker, P.B.; Stribley, D.P. The development of endomycorrhizal root systems. VII. A detailed study of the effects of soil phosphorus on colonisation. New Phytol. 111: 435-446, 1989.

2. Baon, J.B.; Smith, S.E.; Alston, A.M.; Wheeler, R.D. Phosphorus efficiency of three cereals as related to indigenous mycorrhizal infection. Aust. J. Agric. Res. 43: 479-491, 1992.

3. Baptista, E.A. Influência de fatores edáficos no cerrado da reserva biológica de Mogi-Guaçu, SP. Piracicaba, 1988, 188p. (Ph.D. Thesis. Escola Superior de Agronomia "Luiz de Queiróz". USP).

4. Barbosa, L.M.; Barbosa, J.M.; Bedinelli, C.; Asperti, L.M.; Belasque, E.F.; Batista, E.A. Efeitos de geadas em mudas de espécies arbóreas de mata ciliar utilizadas em ensaios. Acta Bot. Brasilica 7: 95-105, 1993.

5. Bononi, V.L.R.; Trufem, S.F.T. Endomicorrizas vesículo-arbusculares do cerrado da Reserva Biológica de Moji-Guaçu, SP, Brasil. Rickia 10: $55-84,1983$.

6. Bruce, A., Smith, S.E.; Tester, M. The development of mycorrhizal infection in Cucumber: effects of P supply on root growth, formation of entry points and growth of infection units. New Phytol. 127: 507514, 1994

7. Cuenca, G.; Meneses, E. Diversity patterns of arbuscular mycorrhizal fungi associated with cacao in Venezuela. Plant Soil 183: 315-322, 1996.

8. Davis, E.A.; Young, J.L.; Rose, S.L. Detection of high P-tolerant vesicular-arbuscular mycorrhizal fungi colonizing hops and peppermint. Plant Soil. 81: 29-36, 1984

9. Dodd, J.C.; Arias, I.; Koomen, I.; Hayman, D.S. The management of populations of vesicular-arbuscular mycorrhizal fungi in acid-infertile soils of a savanna ecosystem. II. The effects of pre-cropping on the spore populations of native and introduced VAM fungi. Plant Soil. 122: 241-247, 1990.

10. Gaur, A.; Adholeya, A.; Mukerji, K.G. A comparison of AM fungi inoculants using Capsicum and Polianthes in marginal soil amended with organic matter. Mycorrhiza. 7: 307-312, 1998.

11. Gerdemann, J.W.; Nicolson T.H. Spores of mycorrhizal Endogone species, extracted from soil by wet sieving and decanting. Trans. Brit. Mycol. Soc. 46: 235-244, 1963.

12. Giovannetti, M.; Mosse, B. An evaluation of techniques for measuring vesicular-arbuscular mycorrhizal infection in roots. New Phytol. 84: 489-500, 1980.

13. Gomes-da-Costa, S.M. Fungos micorrízicos arbusculares em monoculturas e rotações de milho (Zea mays L.) e soja (Glycine max (L.) Merrill. Rio Claro, 1993. 112p. (Ph.D. Thesis. Instituto de Biociências de Rio Claro. Universidade Estadual Paulista).

14. Graciolli, L.A. Efeito do biossuper na cultura de milho (Zea mays L.) em latossolo vermelho-escuro, no município de Selvíria, MS. Rio Claro, 1992. 92p. (Ph.D. Thesis. Instituto de Biociências de Rio Claro. Universidade Estadual Paulista).

15. Habte, M. Soil acidity as a constraint to the application of vesiculararbuscular mycorrhizal technology. In: Varma, A.; Hock, B. (eds.). Mycorrhiza - structure, function, molecular biology and biotechnology. Spring-Verlag, Berlin, 1995, p.593-605.

16. Hayman, D.S. VA mycorrhizas in field crop systems. In: Safir, G.R. (eds.). Ecophysiology of VA mycorrhizal plants. CRC Press, Boca Raton, 1987, p.171-192. 
17. Hayman, D.S.; Tavares, M. Plant growth responses to vesiculararbuscular mycorrhiza. XV. Influence of soil $\mathrm{pH}$ on the efficiency of different endophytes. New Phytol. 100: 367-377, 1985.

18. Hetrick, B.A.D.; Hetrick, J.A.; Bloom, J. Interaction of mycorrhizal infection, phosphorus level, and moisture stress in growth of field corn. Can. J. Bot. 62: 2267-2271, 1984.

19. Jakobsen, I. Research approaches to study the functioning of vesicular-arbuscular mycorrhizas in the field. In: Robson, A.D.; Abbott L.K.; Malajczuk, N. (eds.). Management of mycorrhizas in agriculture, horticulture and forestry Kluwer Academic Publishers, Dordrecht, 1994, p.141-147.

20. Jenkins, W.R. A rapid centrifugal-flotation technique for separating nematodes from soil. Plant Dis. Rep. 48: 692, 1964.

21. Joner, E.J.; Jakobsen, I. Growth and extracellular phosphatase activity of arbuscular mycorrhizal hyphae as influenced by soil organic matter. Soil Biol. Biochem. 27(9): 1153-1159, 1995.

22. Maia, L.C.; Trufem, S.F.B. Fungos micorrízicos vesículo-arbusculares em solos cultivados no estado de Pernambuco, Brasil. Revta Brasil. Bot. 13: 89-95, 1990.

23. Miller, R.M.; Jastrow, J.D. Hierarchy of root and mycorrhizal fungal interactions with soil aggregation. Soil Biol. Biochem. 22: 579-584, 1990.

24. Morton, J.B.; Bever, J.D.; Pfleger, F.L. Taxonomy of Acaulospora gerdemannii and Glomus leptotichum, synanomorphs of an arbuscular mycorrhizal fungus in Glomales. Mycol. Res. 101:625-631, 1997.

25. Phillips, J.M.; Hayman, D.S. Improved procedures for clearing roots for rapid assessment of infection. Trans. Brit. Mycol. Soc. 55: 158161, 1970.

26. Porter, W.M.; Robson, A.D.; Abbott, L.K. Factors controlling the distribution of VA mycorrhizal fungi in relation to soil pH. J. Appl. Ecol. 24: 663-672, 1987.

27. Read, D.J. Mycorrhizas in ecosystems. Experientia. 47: 376-391, 1991.
28. Sieverding, E. Manipulation of indigenous VAM fungi through agronomic practices. In: Sieverding E. (ed.). Vesicular arbuscular management in tropical agrosystems Deutsche Geseellschaft für Technische Zusammenarbeit (GTZ), Eschborn, 1991, p.117-165.

29. Siqueira, J.O.; Collozi-Filho, A.; Oliveira, E. Ocorrência de micorrizas vesículo-arbusculares em agro e ecossistemas de Minas Gerais. Pesq. Agropec. Bras. 24: 1499-1506, 1989.

30. Siqueira, J.O.; Hubbell, D.H.; Mahmud, A.W. Effects of liming on spore germination, germ tube growth on root colonization by vesicular-arbuscular mycorrhizal fungi. Plant Soil. 76: 115-124, 1984.

31. Siqueira, J.O.; Mahmud, A.W.; Hubbell, D.H. Comportamento diferenciado de fungos formadores de micorrizas vesicular-arbuscular em relação à acidez do solo. Rev. Bras. Ciência Solo. 10: 11-16, 1986.

32. Stahl, P.D.; Christensen M. Population variation in the mycorrhizal fungus Glomus mosseae: breadth of environmental tolerance. Mycol. Res. 95: 300-307, 1991.

33. Stutz, J.C.; Morton, J.B. Successive pot cultures reveal high species richness of arbuscular endomycorrhizal fungi in arid ecosystems. Can. J. Bot. 74: 1883-1889, 1996.

34. Trappe, J.M. Phylogenetic and ecologic aspects of mycotrophy in angiosperms from an evolutionary standpoint. In: Safir G.R. (ed.): Ecophysiology of VA mycorrhizal plants CRC Press, Boca Raton, 1987 , p.5-25.

35. Trufem, S.F.B.; Bononi, V.L.R. Micorrizas vesículo-arbusculares de culturas introduzidas em áreas de cerrado. Rickia. 12: 165-187, 1985.

36. Walker, C.; Vestberg, M. Synonymy amongst the arbuscular mycorrhizal fungi: Glomus claroideum, G. maculosum, $G$. multisubstensum and G. fistulosum. Ann. Bot. 82: 601-624, 1998.

37. Weber, O.B.; Oliveira, A.A.R.; Magalhães, A.F.J. Adubação orgânica e inoculação com Glomus etunicatum em porta-enxertos de citros. Rev. Bras. Ciência Solo. 14: 321-326, 1990. 